\section{Борис БАБІН}

\section{Наказ Міжнародного трибуналу 3 морського права як фактор розвитку вітчизняної теорії та практики міжнародного права}

Тези присвячені правовому аналізу наказу Міжнародного трибуналу 3 морського права, згідно 3 яким РФ була зобов'язана негайно звільнити українські кораблі Бердянськ, Нікополь і Яни Капу, повернути їх під контроль України, а також негайно звільнити затриманих українських моряків і дозволити їм повернутися в Україну. У тезах визначено роль даного наказу у розвитку вітчизняної теорії та практики міжнародного права. У тезах також проаналізовано слабкі риси позиції України щодо визначення характеру Керченського інциденту.

Ключові слова: Міжнародний трибунал 3 морського права, Керченський інцидент, свобода судноплавства, збройна агресія Російської Федерації.

This article is devoted to the legal analysis of the order of the International Tribunal for the Law of the Sea and its role for the development of national theory and practice of international law. The article also analyses the weak features of Ukraine's position on determining the nature of the Kerch Strait incident. The first is the imbalance of the State's position on the Kerch Strait incident in various international bodies, for example, in the European Court of Human Rights and ITLOS. The second weak feature of Ukraine's position in the Tribunal is the insufficient level of involvement of legal doctrine. It will have a particular importance when the further dispute over the nature of "military" or "law enforcement" activity in arbitration will be predominantly doctrinal in its nature, as there is simply no consistent international case-law in this area, apart from a few precedents.

Keywords: The International Tribunal for the Law of the Sea, Kerch Strait incident, freedom of navigation, Russian Federation's aggression.

Формування сучасної теорії та практики міжнародного права в України отримало новий поштовх в умовах ескалації міждержавного україно-російського конфлікту, зумовленого російською агресією. Роль у цьому формуванні професора Олександра Задорожнього вбачається безперечною, видані під його егідою у 2014-2015 роках монографічні праці залишаються ключовим дороговказом розвитку вітчизняної міжнародної правової доктрини. Не випадково, що у цих працях, таких як монографія «Українська революція гідності, агресія РФ та міжнародне право» 2014 р. серед іншого згадуються про аспекти міжнародного морського права у його взаємодії із гуманітарним правом та правом прав людини [1, с. 210].

Тому не дивно, що ці питання набули виключної значущості як в рамках ведення Україною справи проти РФ у Арбітражному трибуналі з морського права у рамках арбітражного провадження щодо прав прибережної держави в Чорному, Азовському морях та Керченській протоці [2], що триває з 2016 р. Більш того, ці питання загострилися після нападу 25 листопада 2018 р. силами РФ на кораблі ВМС Збройних сил України у Чорному морі, за підсумками якого Україною було ініційовано окрему справу в Арбітражному трибуналі за Конвенцією про морське право 1982 р. та в рамках якої було подано запит про тимчасові до Міжнародного трибуналу з морського права (ITLOS) [3].

Справа, ініційована Україною 1 квітня 2019 р., стосувалася порушення Росією абсолютного імунітету трьох українських кораблів і двадцяти чотирьох військовослужбовців на борту цих кораблів. 
25 травня 2019 р. ITLOS видав наказ, згідно з яким РФ має негайно звільнити українські кораблі Бердянськ, Нікополь і Яни Капу, повернути їх під контроль України, а також негайно звільнити затриманих українських моряків і дозволити їм повернутися в Україну. Ключові матеріали цього провадження - позиція України, наказ ITLOS, заяви, особливі думки суддів Трибуналу наразі наявні у вільному доступі на сайті ITLOS та можуть бути предметом ретельного наукового аналізу [4].

Єдиним відхиленням від вимог України, яке зробив ITLOS у наказі, стала відсутність вимоги від РФ припинити кримінальні провадження проти моряків (як це пропонувала Україна). Така позиція загалом ITLOS була очікуваною, бо як влучно вказали в наданих до наказу окремих думках судді ITLOS, цей орган не буде та не може втручатися у національні кримінальні провадження. Тому загалом як для ITLOS, так й для міжнародній спільноті у цілому - не цікаві підходи та шляхи виконання РФ цього наказу, вони практично не впливають на міжнародно-правову оцінку ситуації.

Але безумовно шляхи реалізації наказу РФ мають вагоме політико-правове значення для національних інтересів України зокрема у вимірі діяльності ВMC та організації азовського судноплавства. Також важливо спрогнозувати подальші дії РФ та власне сформувати найефективнішу тактику України у обох Арбітражних трибуналів, який будуть розглядати справи проти РФ щодо порушення нею Конвенції 1982 р. по суті, а також й в інших пов'язаних із цими подіями міжнародних провадженнях, зокрема у Європейському суді з прав людини, та, можливо, у Міжнародному кримінальному суді.

Безумовно, факт та формат виконання РФ наказу ITLOS залежатиме від того, чи націлена РФ брати подальшу активну участь у справах в Арбітражних трибуналах (за умов такої участі не виконувати процесуальні рішення є вкрай нерозумним), та чи враховує РФ економічні та політичні ризики ігнорування наказу ITLOS в подальшому. Бо, як власне доводить нинішня справа, і Конвенція OOH 1982 р., і власне ITLOS важливі для захисту правомірних інтересів слабких держав від права сили на морі. Вочевидь РФ розуміє слабкість та вразливість торговельного флоту під власним прапором, торгових суден російських бенефіціарів та з російськими екіпажами на борту, експлуатованих РФ морських трубопроводів а також відповідні ризики для кораблів російського ВМФ за умов дискусійності та обмеженості їх імунітетів.

За будь-яких обставин очевидно, що РФ, виконуючи наказ ITLOS де-факто РФ буде вимагати для себе максимум якихось зустрічних загальних зобов'язань від України, або організації обміну полонених моряків на підконтрольних наразі владі України російських злочинців. Втім після рішення ITLOS Україні наразі вкрай нерозумно йти на будь-які, навіть тактичні, поступки РФ; більш того, саме можливе невиконання РФ наказу ITLOS вкрай вигідно національним інтересам України (хоча й залишає пріоритетним питання боротьби за визволення екіпажів). Припинення РФ внутрішніх кримінальних справ щодо моряків в рамках «амністії», «помилування» тощо не знімає із їх захисту обов'язку доведення невинуватості моряків у міжнародних судах та комітетах, куди їх адвокати зможуть подати окремі, індивідуальні заяви.

Основні ж провокації варто очікувати від РФ у зв'язку із передачею (імітацією передачі) кораблів BMC України на підконтрольну територію України. Тому вже наразі ВМС та військовій прокуратурі варто організувати переконливе обрахування нанесених росіянами кораблям матеріальних та інших збитків, а також - втраченої державою вигоди. Бо саме ці цифри мають бути висвітлені у фінальному рішенні Арбітражного трибуналу, що триватиме проти РФ за Конвенцією 1982 р. найближчі декілька років.

Для прогнозів поведінки РФ у цьому арбітражі ключову роль набувають документи ITLOS - як позиції сторін та власне оголошений наказ, так й згадані три особливих думки суддів, які проголосували «за» (Чжігоу Гао, КНР; Ентоні А. Лакі, Тринидад та Тобаго; Хосе Л. Іісуса, Кабо-Верде), а також дві заяви суддів, що підтримали Наказ (Лісбет Лінгзаад, Нідерланди; Кріангсак Кіттічайсарі, Таіланд). Особливе значення має позиція російського судді Романа Колодкіна, яка вочевидь містить у собі складові подальшої тактики РФ в процесі.

Вочевидь головним питанням в Арбітражному трибуналі стане визначення характеру Керченського інциденту, бо за умов його віднесення до «військової діяльності» процес буле припинено. Поки ITLOS вирішив, що події, пов'язані із протидією росіянами проходу через Керченську протоку та із наступним захопленням кораблів ВМС України, є з боку росіян «правоохоронною діяльністю». Цьому сприяє й «поліцейський» характер протидії росіянами проходу кораблів до їх захоплення, й неналежність суден ПС ФСБ РФ до військових структур РФ, й подальші дії РФ з визначення інциденту як «загально-кримінального злочину».

Захист цієї позиції в арбітражі, особливо зважаючи на наведені особливі думки суддів, які переважно концентрувалися саме на питанні «військової діяльності», вимагатиме від України невідкладних додаткових зусиль. Вкажу на слабкі риси позиції України, так й не усунені до рішення ITLOS. 
По-перше - це розбалансованість позицій держави щодо Керченського інциденту в різних міжнародних органах - прикладом, у Європейському суді та ITLOS, на що прямо вказали у власних окремих думках судді ITLOS Чж. Гао та К. Кіттічайсарі. Наразі варто визначити пріоритети - яке 3 цих проваджень є основним, а яке - має корегуватися. Вважаю що Арбітражний трибунал виглядає перспективнішим, бо рішення у ньому буле схвалено швидше, воно матиме глобальне, а не регіональне значення та вочевидь, зважаючи на сумний розвиток справ у системі Ради Європи, буде більш неупередженим.

Також у цьому вимірі варто визначитися із перспективами застосування норм Римського статуту та III Женевської конвенції; наразі це здійснюється Україною та захистом моряків насамперед через політичні заяви про полонених у міжнародних організаціях, в рамках стратегії захисту моряків у кримінальних справах в РФ та в порядку порушених проваджень за ст. 438 КК проти російських слідчих та суддів, які порушують права полонених.

Втім ці юридичні позиції наразі вочевидь, на відміну від рішення Арбітражного трибуналу (чи ССПЛ) не призведуть до реального кінцевого правового результату. Адже вони прикладом не впливають на вже здійснені цивілізованими країнами світу заяви із засудженням РФ. Кримінальні справи в РФ наразі мають значення виключно як докази порушень прав моряків російською владою, а заочні провадження проти російських слідчих, прокурорів та суддів у цих справах за 438 КК в Україні, мають вкрай обмежену практичну перспективу.

Вагоме значення кваліфікація за Римським статутом подій у Керченській протоці та поводження 3 полоненими моряками у наступному матиме за умов подання Україною матеріалів до Міжнародного кримінального суду. Важко навести будь-яку правову проблему для організації наразі такого подання; більш того, у нинішньому наказі ITLOS чітко вказано що позиція України стосовно статусу моряків як полонених не впливає на застосування щодо Керченського інциденту Конвенції 1982 р.; цю позицію поділяє й низка провідних науковців. Крім того виникає питання національної правової кваліфікації самого нападу росіянами на кораблі ВMC, яке наразі військова прокуратура розслідує це за ст. 437 як акт агресії. Водночас зважаючи на позицію, висловлену ITLOS, на окремі думки його суддів та враховуючі на наступну аргументи РФ у процесі цілком можливим є кваліфікація нападу на кораблі ВМС України як акт віроломства. Адже кораблі ВМС є законним об'єктом нападу росіян за умов міждержавного конфлікту, але не є таким об'єктом якщо позиція сторін конфлікту свідчить про домовленості між ними (або встановлені іншими структурами зобов' язання) про припинення вогню.

Другою слабкою рисою у позиції України в Трибуналі слід вважати явно недостатній рівень залучення правової доктрини. Це набуває особливого значення, коли подальший спір щодо природи «військової» або «правоохоронної» діяльності у арбітражі буде мати переважно доктринальний характер - бо сталої міжнародної судової практики у цій сфері, крім декількох прецедентів, просто немає. Тому профільні установи (Національна академія правових наук, Дипломатична академія, Українська асоціація міжнародного права, інші ключові наукові структури) та об'єднані ними фахівці мають невідкладно провести потужну роботу в цій сфері - починаючи від організації перекладу та популяризації документів Трибуналу у справі проти РФ та завершуючи організацією міжнародних дискусій із залученням ключових фахівців глобального рівня, здійснити узагальнення відповідної наукової бази, формулювати пропозиції владі. Отже попереду багато роботи та реалізація хоча б частини із можливих завдань стосовно підвищить шанси України на перемогу в Арбітражному трибуналі, а отже - й на майбутніх переговорних майданчиках з свободи судноплавства та деокупації Криму.

1. Українська революція гідності, агресія РФ та міжнародне право : кол. монографія / під заг. ред А. В. Задорожного [М.О. Баймуратов, Б.В. Бабін, Ю.В. Волошин та ін.]. - К. : К.І.С., 2014. - 1116 с.

2. Заява МЗС України щодо інформування Арбітражного Трибуналу, який розглядає спір між Україною та Російською Федерацією, про загострення ситуації в Керченській протоці, Азовському та Чорному морях / 03 грудня 2018 ; URL : https://greece.mfa.gov.ua/ua/press-center/comments/9578zajava-mzs-ukrajini-shhodo-informuvannya-arbitrazhnogo-tribunalu-jakij-rozglyadaje-spir-mizhukrajinoju-ta-rosijsykoju-federacijeju-pro-zagostrennya-situaciji-v-kerchensykij-protoci-azovsykomu-tachornomu-moryah-28-listopada-1925

3. Заява Міністерства закордонних справ України щодо наказу Міжнародного трибуналу 3 морського права / 25 травня 2019 ; URL : https://mfa.gov.ua/ua/press-center/news/72835-zajavaministerstva-zakordonnih-sprav-ukrajini-shhodo-nakazu-mizhnarodnogo-tribunalu-z-morsykogo-prava

4. Case concerning the detention of three Ukrainian naval vessels (Ukraine v. Russian Federation), Provisional Measures / ITLOS ; URL : https://www.itlos.org/cases/list-of-cases/case-no-26/ 


\section{Summary}

In 2014 Russian Federation occupied the Autonomous Republic of Crimea and the city of Sevastopol, which is the integral part of the territory of Ukraine. The international organizations, including, but not limited to United Nations General Assembly and the Parliamentary Assembly of the Council of Europe adopted a number of resolutions and decisions on the situation in the Autonomous Republic of Crimea and the city of Sevastopol, in which they condemned the occupation and didn't recognize the annexation of the Autonomous Republic of Crimea and the city of Sevastopol, supported the territorial integrity of Ukraine, emphasized the non-legitimacy of the so-called "referendum" in the Autonomous Republic of Crimea and the city of Sevastopol and its results, as well as the negative situation with human rights in this territory.

On November 25, 2018, as Ukrainian Navy ships sailed from the Black Sea to the Azov Sea, they were stopped by a Russian tanker that blocked the passage under the occupied force of the Kerch Bridge. Ukrainian ships were attacked by Russian Navy and Coast Guard forces. On May 10, 2019, open hearings at the International Tribunal for the Law of the Sea (ITLOS) on the illegal seizure of 3 Ukrainian boats and 24 sailors began. The case, initiated by Ukraine, concerned the violation by Russia of the absolute immunity of three Ukrainian ships and twenty-four servicemen aboard these ships. On May 25, 2019, ITLOS issued an order requiring the Russian Federation to immediately release Ukrainian ships of Berdyansk, Nikopol and Yana Kapu, return them to Ukrainian control, and immediately release detained Ukrainian sailors and allow them to return to Ukraine.

This article is devoted to the legal analysis of the abovementioned order of the International Tribunal for the Law of the Sea and its role for the development of national theory and practice of international law. The article also analyses the weak features of Ukraine's position on determining the nature of the Kerch Strait incident. The first is the imbalance of the State's position on the Kerch Strait incident in various international bodies, for example, in the European Court of Human Rights and ITLOS. The second weak feature of Ukraine's position in the Tribunal is the insufficient level of involvement of legal doctrine. It will have a particular importance when the further dispute over the nature of "military" or "law enforcement" activity in arbitration will be predominantly doctrinal in its nature, as there is simply no consistent international case-law in this area, apart from a few precedents. 